\title{
Influence of Injection Strategy on B20MOME Fueled CRDI Engine with Toroid Shaped Piston Cavity
}

\author{
Prashanth Kumar ${ }^{1}$, Nagaraj R. Banapurmath ${ }^{2}$, Peter Fernandes ${ }^{3}$, Raju K. ${ }^{1}$ \\ ${ }^{1}$ Department of Mechanical Engineering, SJEC, Vamanjoor, Mangaluru, Karnataka, INDIA \\ ${ }^{2}$ KLE Technological University, BVB College of Engineering and Technology, Hubballi, INDIA \\ ${ }^{3}$ Department of Mechanical Engineering, AIET, Moodbidri, Karnataka, INDIA
}

*Corresponding Author: nrbanapurmath@gmail.com

Citation: Kumar, P., Banapurmath, N. R., Fernandes, P. and Raju, K. (2019). Influence of Injection Strategy on B20MOME Fueled CRDI Engine with Toroid Shaped Piston Cavity. European Journal of Sustainable Development Research, 3(3), em0086. https://doi.org/10.20897/ejosdr/3974

Published: March 21, 2019

\begin{abstract}
New technologies in the fuel injection system have improved the performance of the CI engine. Even though the biodiesel is universally accepted as a suitable alternate fuel for the CI (compression ignition) engine, there have been limited study reported on its utilization for single cylinder CRDI (common rail direct injection) engine. Use of biodiesel with diesel in a CRDI engine reduces proportionate consumption of diesel. In the present study, performance and combustion tests were carried out with the CRDI engine using the B20 blend of mahua methyl ester in diesel on volume basis called (B20 MOME). This study was conducted on a CRDI converted variable compression ratio engine with toroidal shaped cavity in the piston adopted. The tests were carried out at three injection pressures of $400 \mathrm{bar}, 600 \mathrm{bar}$ and $800 \mathrm{bar}$ and for three injection timings of $15^{\circ} \mathrm{BTDC}, 20^{\circ} \mathrm{BTDC}$ and $25^{\circ} \mathrm{BTDC}$, respectively. The results of the combustion and performance tests with the CRDI engine were compared with the performance of a CI engine at specified operating conditions with mechanical injection system using diesel as the fuel. The results indicated significant increase in the performance of the engine with increase of injection pressure. At 800 bar injection pressure, brake thermal efficiency of 29.98\%, 27.61\%, and 26.98\% was attained at 15BTDC, 20BTDC and 25BTDC, injection timing respectively using B20 MOME.
\end{abstract}

Keywords: B20 MOME, CRDI, emissions, injection pressure, injection timing, combustion characteristics

\section{INTRODUCTION}

There is increased thrust for use on renewable and nature friendly fuels in the compression ignition engines to cater to the solution to twin problems, such as source of energy and pollution control. The ability of biodiesel to mix with petrodiesel at any proportion without any additional processing puts an edge over other alternative fuels for the CI engine. Its advantages in terms of renewability, reduced problem to the environment and opportunity to improve the economy and revive environment, has encouraged the researcher to work further more on this fuel. Biodiesel in CI engines has proved for its increased combustion efficiency due to its oxygen content. The problem with higher viscosity and the density of biodiesel has restrained its use in the CRDI engine. Extensive studies on the performance of blends of mahua biodiesel on CI engine have been publicized. Puhan et al. (2009) reported lower ignition delay and higher peak pressure at higher injection pressures with mahua methyl ester compared with diesel. Matching combustion duration was reported at all injection pressures. Mohan et al. (2014) reported the performance at various nozzle opening pressures (NOP) $(225,250$, and $275 \mathrm{bar}$ ) and static injection timings $\left(19^{\circ}, 21^{\circ}, 23^{\circ}, 25^{\circ}, 27^{\circ}\right.$ BTDC) and stated stringent emission norms can be attained with B20 mahua bio- 
diesel without compromising the performance against diesel. Nanthagopal et al. (2016) reported that increased brake specific fuel consumption of a $\mathrm{C}$. inophyllum methyl ester fuelled engine had been reduced to a great extent with higher injection pressure.

Recent developments in the CI engine fuel injection system have raised opportunities' to enhance its performance by controlling the different injection parameters of the engine. The state of air in to which the fuel injected, changes as fuel injection timing is varied and effects ignition delay. The fuel injection rate, fuel nozzle design, and fuel injection pressure effects the characteristics of the fuel spray and its mixing with air in the combustion chamber.

Heywood (1988) observed higher injection rate results in higher fuel air mixing rates and hence higher heat release rates. As the injection rate increased, optimum injection timing moved towards the top dead centre. Higher heat release rate and shorter overall combustion process that resulted from increased injection rate decreases the minimum BSFC at optimum injection timing. Jindal et al. (2010) reported combined increase of compression ratio and injection pressure increases the brake thermal efficiency (BTE) and lowers emissions. Scholl et al. (1993) reported that smaller orifice diameter gave higher cylinder pressure and maximum rate of pressure increase, higher NOx emissions, and a larger amount of premixed burning of fuels.

The variation of injection timing had a pronounced effect on performance and emissions.

Nwafor et al. (2000) reported that longer delays between injection and ignition led to unacceptable rates of pressure rise with the result of diesel knock because too much fuel was ready to take part in premixed combustion. Alternative fuels exhibit longer delay periods and slower burning rate at low load operating conditions, hence, result in late combustion in the expansion stroke. Moderate advanced injection timing is recommended for low speed operations. Kannan and Anand (2012) reported that combined effect of higher injection pressure of 280 bar and an advanced injection timing of $25.5^{\circ}$ BTDC had significant improvement in the brake thermal efficiency, cylinder gas pressure, and heat release rate. Sayin et al. (2012) conducted study on engine at constant speed and at different loads with four different injection pressures (18, 20, 22, and $24 \mathrm{MPa})$. This investigation on the injection characteristics of the fuels showed that using COME (cotton seed oil methyl ester), instead of diesel resulted in earlier injection timings. Maximum cylinder pressure, maximum rate of pressure rise and the maximum heat release rate were slightly lowered for COME and its blends. Ganapathy et al. (2011) reported the effect of advance in injection timing from factory settings and concluded increase in BTE, Pmax (Maximum peak pressure), HRRmax (Maximum Heat Release Rate) and NO emission with Jatropha biodiesel operation. At $15 \mathrm{Nm}$ load torque, 1800 rpm engine speed, and 340 crank angle degree (CAD) injection timing, the percentage increase in BTE, Pmax, HRRmax, and NO emission were found to be $5.3 \%, 1.8 \%, 26 \%$ and $20 \%$ respectively. The advent of the highpressure electronic injection system has facilitated reduced emission problems related to CI engine. The use of biodiesel with the electronic injection system has its limitations due to small orifice diameter of the injectors. Agarwal et al. (2013) reported higher cylinder pressure and rate of heat release for lower FIPs. BTE increased with increased injection pressures. For advanced SOI, BMEP and BTE increased, and exhaust gas temperature reduced significantly. Hwang et al. (2014) conducted tests on diesel engine at two injection pressures (80 and $160 \mathrm{MPa}$ ) and different injection timings from 25 to 0 crank angle degrees (CAD) under two different engine loads. The results revealed that the indicated specific fuel consumption (ISFC) with respect to the injection timings of the biodiesel was higher than that of the diesel fuel under all experimental conditions. The peak cylinder pressure and the peak heat release rate of the biodiesels were slightly lower, while the ignition delay was slightly longer under all operating conditions. Bruneaux et al. (2011) studied the spray tip penetration of KOME10, KOME20 and mineral diesel and reported that higher fuel injection pressures lead to longer spray tip penetration than observed at lower injection pressure for the same elapsed time after the SOI. Spray penetration reduced with increasing spray chamber pressure. High-pressure injection of KOME20 lead to finer droplet size distribution in the spray because higher fuel pressure differential causes the fuel to be discharged from injection nozzle in the form of smaller droplets. Improved atomization at the nozzle outlet, results in a more distributed vapor phase at higher injection pressure, hence resulting in better mixing. Precisely controlled injection, with high accuracy of fuel metering, control the power output and limit the smoke as well. Controlled initial rate of injection, further reduces noise and emissions. Injection pressure, sharp end of injection to eliminate nozzle dribble, prevent nozzle fouling and reduce smoke and hydrocarbon emissions. Different studies have been carried out to study the effect of combustion chamber design on the performance of CI engine and reported that with toroidal bowl in piston, increased swirl ratio shifts minimum BSFC closer to TDC. Heywood (1988) explained increased air entrainment in combustion chamber which resulted in the improved combustion efficiency with toroidal combustion chamber. Jaichandara et al. (2012) reported increased BTE for the toroidal combustion chamber. Similar works by the same author Jaichandara et al. (2012) further optimized the combination of injection timing and combustion chamber geometry to achieve higher performance and lower emission from biodiesel fueled diesel engines. Toroidal Re-entrant Combustion Chamber (TRCC) geometries showed an improvement of 5.64\% in the brake thermal efficiency. Lee (2016) studied Spray and Combustion Characteristics of B5 and B20 of soyabean oil in a Direct Injection Common-Rail Diesel engine 
and reported, higher biodiesel blend needs higher injection pressure to achieve the similar injection rate. The similar spray tip penetration observed for biodiesel and diesel. Atomization characteristics of biodiesel show that it has higher sauter mean diameter and lower spray velocity than conventional diesel fuel due to high viscosity and surface tension. The peak combustion pressures of diesel and blending fuel increased with advanced injection timing and the combustion pressure of biodiesel fuel is higher than that of diesel fuel. As the injection pressure increased to $100 \mathrm{MPa}$, the combustion pressure and rate of heat release increased. As the blending ratio of biodiesel increased from $5 \%$ to $20 \%$, the combustion pressure and heat release rate increased a little. Kumar et al. (2018) reported study of three different nozzle, each of the nozzles with 3 injection holes, with the aperture of $0.20 \mathrm{~mm}$ (modified), $0.28 \mathrm{~mm}$ (base), and $0.31 \mathrm{~mm}$ (modified) with diesel and B20 as fuels. The improved BSFC with the B20 fuel and with smaller orifice NHD (Nozzle hole diameter). The maximum peak pressure was increased for smaller orifice $0.20 \mathrm{~mm}$ NHD with B20 fuel due to good atomization, increase the cone angle, good fuel mixing. The HRR indicate that the shorter ID (ignition delay) generated for smaller orifice NHD, earlier SOC is resulted in less amount of fuel is mixed with air at the time of ignition. This results by decreasing the premixed combustion with reduced orifice NHD. Maciej Mikulski et al. (2018) Compared the performance and emissions of a CRDI diesel engine fuelled with biodiesel of different origin and reported, increased peak pressure with increased engine load for all tested fuels, The Pmax value is also largely influenced by the start of the combustion angle. The R75 (rape seed oil) sample resulted in Pmax values much closer to the reference fuel. The animal fat-based fuels resulted in considerably higher Pmax values. For 1500 RPM, all biofuel showed higher PRR values with significant difference at high load operation. R75 showed the most similar performance regarding pressure rise rate compared to MD. The slightly retarded injection point causes the same shift at the start of combustion. This is despite significantly lower pressures and temperatures during compression, which suggests a shortened chemical ignition delay for S75 compared to MD. Also, similar behavior is well recognizable for 3000RPM and $50 \mathrm{Nm}$, especially for S75 mixtures. The increased SOI resulted in a proportional shift in the ignition point (SOC), and as a consequence a much higher Pmax value was achieved by the engine powered by S75 and P75 mixtures in relation MD and R75 at the same operating points. In the case of a single injection, the combustion characteristics of the two fuels were very similar. HRR profiles for all the fuels in these cases show similar maximum values. Banapurmath et al. (19) observed a paradigm shift for mechanical direct injection diesel engines to advanced injection strategies of diesel homogeneous charge compression ignition (HCCI) engines. Most of the works on biodiesel-fuelled engines make use of conventional fuel injection systems have limited IOP up to $300 \mathrm{bar}$, which leads to poor BTE and higher emissions. The studies on CRDI arrangement using ECU for a single cylinder four-stroke diesel engine powered with nonedible biodiesel is scantily reported. Singh et al. (20) evaluated fuel injection strategies for biodiesel-fueled CRDI Engine Development and Particulate emission. The effects of various fuel injection parameters including SoMI (Start of Main Injection) timings and FIP on combustion, performance, emissions, and particulate characteristics were investigated. The experiments with three FIPs (400, 700, and $1000 \mathrm{bar}$ ) and four SoMI timings (4, 6, 8, and $10^{\circ}$ bTDC) using mineral diesel, B20, and B40 as fuel in conventional CI combustion engine showed that all the test fuels had almost similar combustion characteristics. Pmax and HRR were the maximum at 1000 bar FIP; however excessive knocking restricted the application of higher FIPs. Advancing SoMI timings also showed similar combustion characteristics for all the test fuels. Slightly advanced SoMI timings (6obTDC) at higher FIP (700 bar) were found to be the most suitable injection strategy for conventional CI combustion using these test fuels. BTE was found to be slightly higher at 700 bar FIP.

From the exhaustive literature survey carried out on the feasibility studies of high pressure injection biodiesel engine operation and their blends, limited work has been reported. Further the effect of combustion chamber on the biodiesel blended fuels usage in CRDI engines has not been investigated. Also, studies on single cylinder CRDI engine fueled with B20 MOME and effect of combustion chamber shape on the engine performance has scantily been reported. Hence the objective of the present work is to determine the optimized parameters in terms of injection parameters (IT, IOP) and combustion chamber shapes for maximized CRDI engine performance with B20 MOME.

\section{EXPERIMENTAL SET - UP AND METHODOLOGY}

\section{Fuels Used and its Properties}

Madhuca indica, commonly known as mahua belonging to the sapotaceae family has been used as the base feedstock in this study. B20 MOME (20\% blend of mahua methyl ester on volume basis with diesel) has been used as the fuel. The basic properties required for the study such as calorific value, viscosity and density were determined as per the ASTM standards. The properties are as shown in Table 1. 
Table 1. Properties of biodiesel, diesel, and B20 MOME

\begin{tabular}{ccccc}
\hline Properties & ASTM standard & Diesel & MOME100 & B20 MOME \\
\hline Density $\left(\mathrm{kg} / \mathrm{m}^{3}\right)$ & D1298 & 840 & 890 & 848 \\
\hline Calorific value, $\mathrm{kJ} / \mathrm{kg}$ & ASTM 240 & 43796 & 38375 \\
\hline Viscosity $(\mathrm{cst})$ & ASTM D445 & 3.02 & 41285 \\
\hline
\end{tabular}

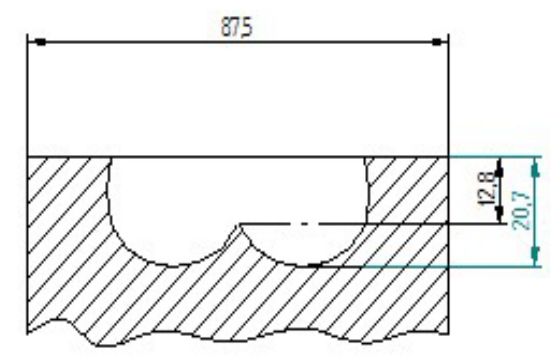

Figure 1. Toroidal shape of the piston cavity

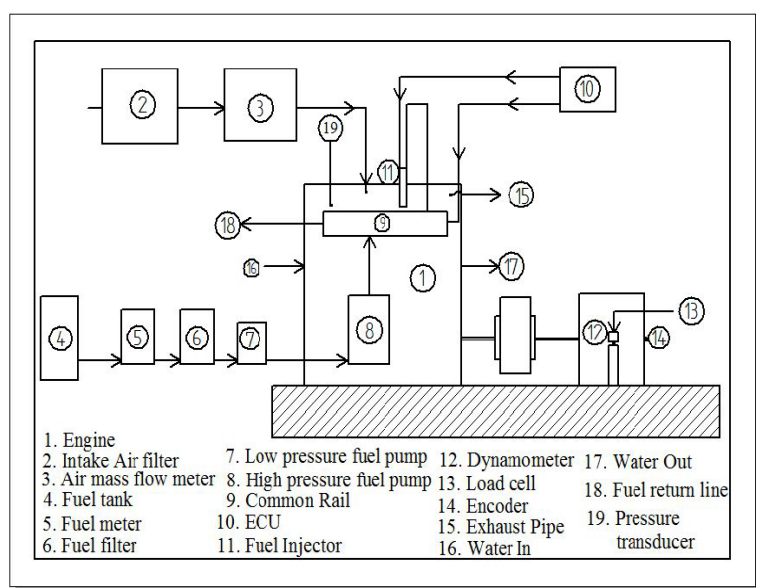

Figure 2. Diagram of CRDI engine test rig

\section{Modification of Piston}

The conventional diesel engine has hemispherical bowl (HCC) in the piston. The toroidal shaped bowl was obtained by modifying the existing bowl keeping the same bowl volume as that of the HCC. The shape of the cavity was modified with larger bowl entrance diameter without altering the compression ratio of the engine. The modified shape of the piston cavity is shown in Figure 1.

Experiments were carried on two similar engines with the same specifications and rated power, but with different types of fuel injection systems. Figure 2 shows a schematic diagram of the CRDI engine test rig. The engine test rig is fully instrumented for measuring combustion pressure, load on engine, mass flow rate of fuel and air flow rate. In the first phase, the experiments were conducted on an engine with CMFIS (Cam operated mechanical fuel injection system) using diesel as the fuel under standard settings of the engine with a hemispherical cavity in the piston at rated load. The performance and combustion results of these experiments with diesel were considered as a basis for comparison. In the second phase, the experiments were conducted on a CRDI engine with a toroidal shaped cavity in the piston without altering the engine specifications. The experiments are carried out at three injection pressures, 400bar, 600bar and 800 bar. Maximum injection pressure was limited to 800 bar, due to knocking in the engine. The results such as brake thermal efficiency, exhaust gas temperature, net heat release rate and peak pressure were obtained from the results. The injection timing was of $15^{\circ} \mathrm{BTDC}, 20^{\circ} \mathrm{BTDC}$ and $25^{\circ} \mathrm{BTDC}$. Beyond these injection timings the performance deteriorated. The mean values of the results were used for discussion. The specifications of the engine and injector are given in Table 2. 
Table 2. Specification of the engine test rig

\begin{tabular}{|c|c|c|c|c|c|}
\hline Sl. No. & Part & Specification & S1. No. & Part & Specification \\
\hline 1 & Product & CRDI, VCR Engine (Computerized) & 6 & Load sensor & $\begin{array}{l}\text { Make -VPG Sensotronics, } \\
\text { Load cell, type strain gauge, } \\
\text { range } 0-50 \mathrm{~kg}\end{array}$ \\
\hline 2 & Engine Make & $\begin{array}{l}\text { Kirloskar, Single cylinder, } 4 \text { stroke, water } \\
\text { cooled, stroke } 110 \mathrm{~mm} \text {, bore } 87.5 \mathrm{~mm} \text {, } \\
661 \mathrm{cc} \text {. Power } 3.5 \mathrm{~kW}, 1500 \mathrm{rpm}\end{array}$ & 7 & $\begin{array}{l}\text { Dynamometer } \\
\text { Type }\end{array}$ & $\begin{array}{l}\text { Eddy current, water cooled with } \\
\text { loading unit }\end{array}$ \\
\hline 3 & ECU Model & $\begin{array}{c}\text { Nira i7r (with solenoid injector driver) } \\
\text { with programmable ECU }\end{array}$ & 8 & Injector & Make-Bosch \\
\hline 4 & Common rail & $\begin{array}{l}\text { With pressure sensor and Pressure } \\
\text { regulating valve Solenoid driven Piezo } \\
\text { sensor, Make PCB USA, }\end{array}$ & 9 & No. of holes & 6 \\
\hline 5 & Temperature sensor & Make Radix, Type RTD, PT100 & 10 & Orifice diameter & $0.128 \mathrm{~mm}$ \\
\hline
\end{tabular}

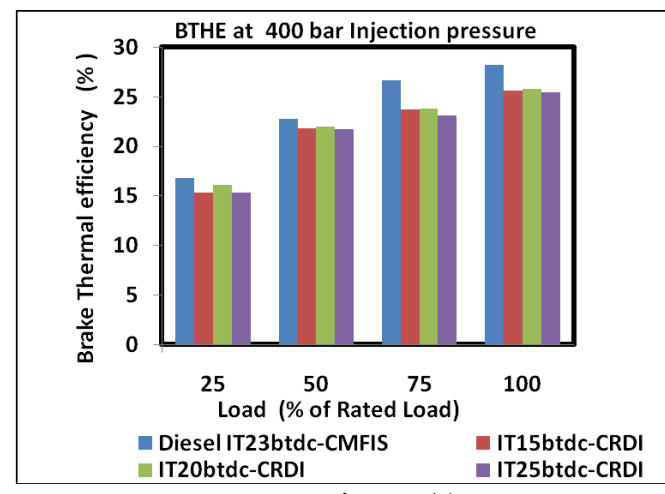

Figure (a)

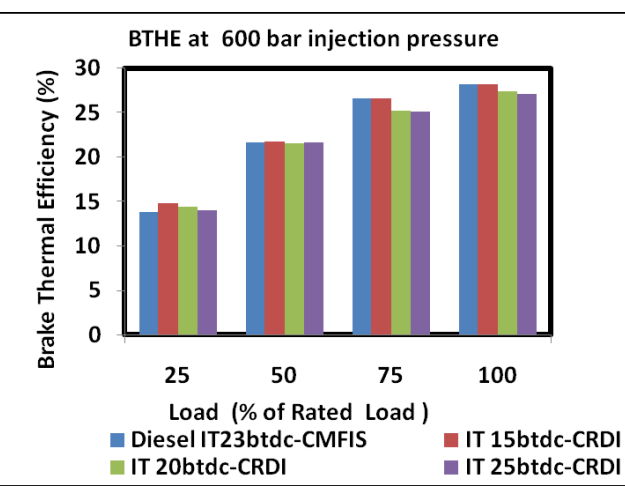

Figure (b)

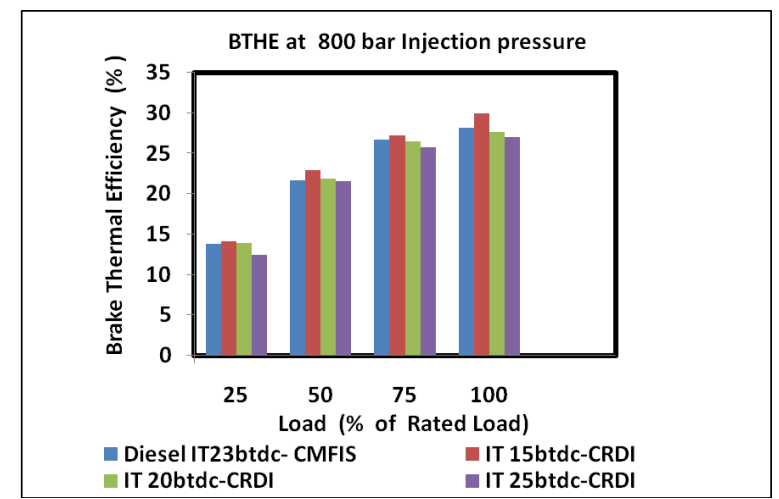

Figure (c)

Figure 3. Effect of injection timing on BTHE at (a) 400, (b) 600, and (c) 800 bar injection pressures

\section{RESULTS AND DISCUSSION}

\section{Comparative Performance of CI engine with Diesel and CRDI Engine with B20 MOME}

The performance characteristics of an engine were evaluated based on the BTE since injection pressure and timing are the influencing factors that establish the energy conversion efficiency of the engine. The results at rated load are discussed in this section.

Figures $3(\mathrm{a}, \mathrm{b}, \mathrm{c})$ present a comparison of brake thermal efficiencies of the CI with diesel and a CRDI engine with B20 MOME as fuel at 400 , 600, and 800 bar injection pressure and three different injection timings. The $\mathrm{BTE}$ of both the engines are compared at rated load on the engine. At 400 bar injection pressure, the BTE of the CRDI engine with B20 MOME as fuel was smaller compared with the CMFIS (cam operated mechanical fuel injection system) engine with diesel as fuel. The maximum thermal efficiency was found to be $28.17 \%$ for diesel as fuel with the CMFIS engine. With the CRDI engine, for B20 MOME at 400 bar injection pressure the brake thermal efficiency obtained were $25.6 \%, 25.75 \%$ and $25.39 \%$ at $15^{\circ} \mathrm{BTDC}, 20^{\circ} \mathrm{BTDC}$, and $25^{\circ} \mathrm{BTDC}$, respectively. For the CRDI engine at 400 bar injection pressure, the atomization of the fuel with higher viscosity and density is inferior compared with high injection pressure. This may have resulted in poor conversion efficiency. At $15^{\circ}$ BTDC 


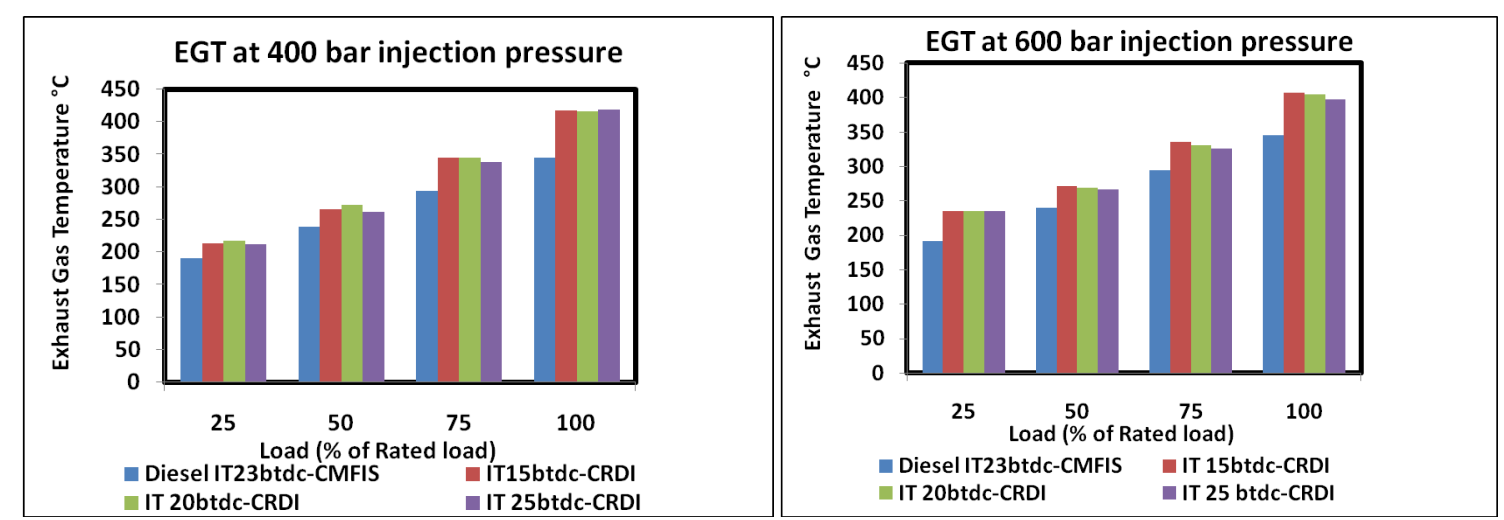

(a)

(b)

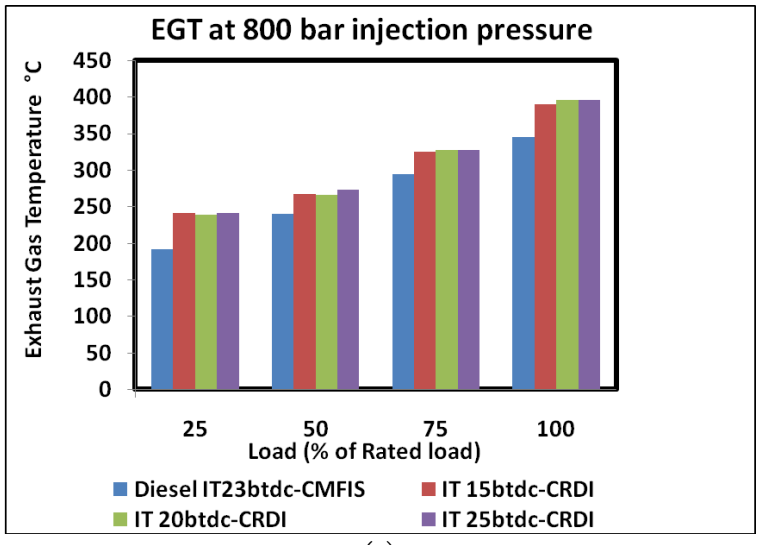

(c)

Figure 4. Effect of injection timing on EGT at 400, 600, and 800bar injection pressure

the inferior performance observed may be due to expansion losses of the engine, and at $25^{\circ} \mathrm{BTDC}$, lowered performance could be due to lowered compression losses.

Figure 3(b) shows the performance of the CMFIS engine with diesel and CRDI engine with B20 MOME as fuel at 600 bar injection pressure. The BTE of the engine increased with the increase in injection pressure. Among the three injection timings, the BTE was better with $15^{\circ}$ BTDC when compared with $20^{\circ}$ BTDC and $25^{\circ}$ BTDC. The BTE of the engine at $600 \mathrm{bar}$ injection pressure and three injection timings $15^{\circ} \mathrm{BTDC}, 20^{\circ} \mathrm{BTDC}$, and $25^{\circ} \mathrm{BTDC}$ were $28.75 \%, 27.45 \%$ and $27.14 \%$ respectively. The distinction of the brake thermal efficiencies between mechanical injection system with diesel and CRDI injection system with B20MOME had narrowed as the fuel injection pressure was increased. The brake thermal efficiency at advanced injection was lower and may be due to compression losses of the engine.

Figure 3(c) shows the comparison of the brake thermal efficiencies between a CI engine with diesel as fuel and CRDI engine with B20MOME as fuel at 800 bar injection pressure. At 800 bar injection pressure and $15^{\circ} \mathrm{BTDC}$, the brake thermal efficiency exceeded the BTE of the CI engine with CMFIS powered with diesel as fuel. The brake thermal efficiency at three injection timings of $15^{\circ} \mathrm{BTDC}, 20^{\circ} \mathrm{BTDC}$, and $25^{\circ} \mathrm{BTDC}$ were $29.98 \%$, $27.61 \%$ and $26.98 \%$ respectively. The size of the droplet plays a basic role in the rate of the combustion process. The rate of the fuel evaporation droplets is proportional to the surface area of the drop. At higher injection pressure, better atomization of the fuel lead to better entrainment of fuel with air and evaporation of the fuel and its ensuing combustion in the gaseous phase. The outcome of better mixing of air and fuel is increased combustion efficiency of the engine. Near TDC the air is compressed to higher extent than, at $25^{\circ}$ BTDC and $20^{\circ}$ degree BTDC. This might have lead to higher air temperature. These two factors have significant effect on initiating the combustion and maintaining combustion rate.

\section{Influence of Injection Strategy on Exhaust Gas Temperature}

Exhaust gas temperature is an indicator of the combustion duration. Extended combustion duration results in increased EGT. Figure 4(a, b, c) shows the effect of injection timing on exhaust gas temperature of the CRDI engine powered with B20MOME and CI engine with diesel as fuel. Exhaust gas temperature increases with the increase in load due to increased fuel consumption, while maximum exhaust gas temperature arises at rated load on the engine. Exhaust gas temperature is lower for engine with CMFIS compared with CRDI engine with B20 MOME as fuel. At 400 bar injection pressure, maximum exhaust gas temperature occurs at rated load of $344.62^{\circ} \mathrm{C}$ for diesel at injection timing of $23^{\circ} \mathrm{BTDC}$, and $417.61^{\circ} \mathrm{C} 416.89^{\circ} \mathrm{C}$ and $419.49^{\circ} \mathrm{C}$, for B20MOME at $15^{\circ} \mathrm{BTDC}$, 


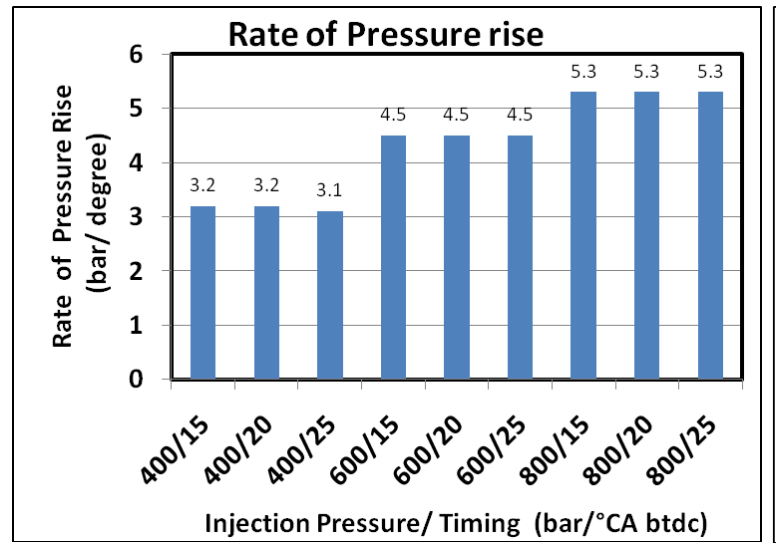

(a)

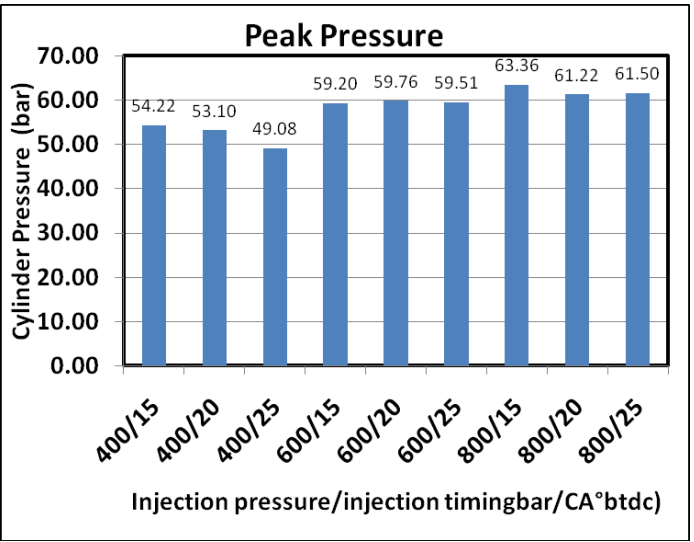

(b)

Figure 5. Effect on injection pressure and timing on rate of pressure rise and peak press

$20^{\circ}$ BTDC and $25^{\circ}$ BTDC respectively. Oner and Altun (2009) reported increased exhaust gas temperature of $440^{\circ} \mathrm{C}$ for B20 blends and cited complete combustion and longer after burning stage due to higher viscosity as the reason for the higher exhaust temperature.

At 600 bar injection pressure, the exhaust gas temperature lowered. EGT was $344.2^{\circ} \mathrm{C}$ at $23^{\circ}$ BTDC with CMFIS and $406.25^{\circ} \mathrm{C}, 404.4^{\circ} \mathrm{C}$ and $397.28^{\circ} \mathrm{C}$ respectively at $15^{\circ} \mathrm{BTDC}, 20^{\circ} \mathrm{BTDC}$ and $25^{\circ}$ BTDC with CRDI system respectively. At 800 bar injection pressure, the exhaust gas temperature was further lowered. EGT were $344.2^{\circ} \mathrm{C}$ at $23{ }^{\circ} \mathrm{BTDC}$ with CMFIS, and $389.43^{\circ} \mathrm{C}, 395.25^{\circ} \mathrm{C}, 395.08^{\circ} \mathrm{C}$ respectively at $15^{\circ} \mathrm{BTDC}, 20^{\circ} \mathrm{BTDC}$ and $25^{\circ} \mathrm{BTDC}$ with CRDI system.

\section{Combustion Characteristics at Rated Load on CRDI Engine with B20 MOME}

Combustion characteristics such as peak cylinder pressure and rate of pressure rise, for three injection pressures of 400,600 and $800 \mathrm{bar}$ and at three injection timings of $15^{\circ} \mathrm{BTDC}, 20^{\circ} \mathrm{BTDC}$ and $25^{\circ} \mathrm{BTDC}$ are discussed in this section. Each set of these independent parameters are expressed as function of Injection pressure/Injection timing for the discussion.

\section{Effect of Injection Pressure and Timing on Rate of Pressure Rise}

Figure 5 shows the rate of pressure rise for three injection pressure and timings. The rate of pressure rise increased with the increase in injection pressure. The effect of injection timing on the rate of pressure rise is marginal compared with effect of injection pressure. Enhanced atomization and vaporization of fuel can be the influencing aspect for the rate of pressure rise. The effect of these aspects appear in improved mixing of air and fuel and better combustion. This results in higher rate of pressure rise with increased injection pressure. Thermodynamic conditions of the combustion chamber during the time of fuel injection effect the rate of combustion. The maximum rate of pressure occurs at 800 bar injection pressure at the rate of $5.3 \mathrm{bars} / \mathrm{deg}$.

\section{Effect of Injection Pressure and Timing on Peak Cylinder Pressure}

Figure 5(b) shows the peak pressure for three injection pressure and timings. The peak cylinder pressure at 400 bar injection pressure were $54.22 \mathrm{bar}, 53.10 \mathrm{bar}$ and 49.08 bar occurred at angles of $375^{\circ}, 375^{\circ}, 375^{\circ} \mathrm{BTDC}$ for the injection timing of $15^{\circ} \mathrm{BTDC}, 20^{\circ} \mathrm{BTDC}$, and $25^{\circ} \mathrm{BTDC}$ respectively, showing the expansion losses due to extended combustion duration. At 600 bar injection pressure, the peak cylinder pressure of $59.2 \mathrm{bar}, 59.76 \mathrm{bar}$ and 59.1 bar occurred at an angle of $373^{\circ}, 372^{\circ}, 373^{\circ}$ for $15^{\circ}$ BTDC, $20^{\circ}$ BTDC and $25^{\circ}$ BTDC respectively. The peak cylinder pressure at an injection pressures of 800 bar was $63.36 \mathrm{bar}, 61.22 \mathrm{bar}$, and $61.50 \mathrm{bar}$ developed at an angle of $372^{\circ}, 372^{\circ}, 372^{\circ}$ for the injection timings of $15^{\circ} \mathrm{BTDC}, 20^{\circ} \mathrm{BTDC}$ and $25^{\circ} \mathrm{BTDC}$ respectively.

\section{CONCLUSION}

The experiments were conducted on CRDI engine powered with MOME (B20) at three injection pressures (400, 600, and 800bar) and three injection timings (15, 20, and 25 BTDC) at constant engine speed of 1500 RPM. The following conclusions were made on the performance and combustion characteristics of single cylinder CRDI engine facilitated with toroidal shaped piston using B20 MOME.

The performance of the engine with the CRDI system improved with increasing injection pressure. The maximum brake thermal efficiency is attained at 800 bar injection pressure and $15^{\circ} \mathrm{BTDC}$ with B20 MOME as fuel. A significant increase in performance was obtained due to injection pressure compared with injection timing. 
As the injection pressure increased to maximum capacity of the engine, the optimum injection timing shifted towards TDC.

The exhaust gas temperature of the CRDI engine with B20MOME as fuel was higher than that of diesel with CMFIS system. The rate of pressure rise is increased with increase in injection pressure while maximum rate of pressure rise and maximum net heat release was obtained at 800 bar injection pressure. The injection timing showed marginal effect on the maximum net heat release rate compared with injection pressure.

\section{ACKNOWLEDGEMENT}

The authors extend their sincere thanks to the Director and Principal of St. Joseph Engineering College, Mangaluru for their support and encouragement to carry out this research work. The authors express their acknowledgement to Mr. S.S Mulae and Mr. Deepak Mulae, for providing the CRDI engine testing facility to conduct experiments at the Apex Innovations Private Limited, Sangli, Maharashtra, India.

\section{REFERENCES}

Agarwal, A. K., Srivastava, D. K., Dhar, A., Maurya, R. K., Shukla, P. C. and Singh, A. P. (2013). Effect of fuel injection timing and pressure on combustion, emissions and performance characteristics of a single cylinder diesel engine. Fuel, 111, 374-383. https://doi.org/10.1016/j.fuel.2013.03.016

Bruneaux, G. (2011). Liquid and vapour spray structure in high-pressure common rail diesel injection. Atomization and Sprays, 11, 533-556. https://doi.org/10.1615/Atomiz Spr. v11.i5.40

Ganapathy, T., Gakkhar, R. P. and Murugesan, K. (2011). Influence of injection timing on performance, combustion and emission characteristics of Jatropha biodiesel engine. Applied Energy, 88(12), 4376-4386. https://doi.org/10.1016/j.apenergy.2011.05.016

Heywood, J. B. (1988). Internal Combustion Engine Fundamentals. New York: McGraw Hill, 1988.

Hwang, J., Qi, D., Jung, Y. and Bae, C. (2014). Effect of injection parameters on the combustion and emission characteristics in a common-rail direct injection diesel engine fueled with waste cooking oil biodiesel. Renewable Energy, 63, 9-17. https://doi.org/10.1016/j.renene.2013.08.051

Jaichandara, S. and Annamalai, K. (2012). Effects of open combustion chamber geometries on the performance of pongamia biodiesel in a DI diesel engine. Fuel, 98, 272-279. https://doi.org/10.1016/j.fuel.2012.04.004

Jaichandara, S., Kumar, P. S and Annamalai, B. K. (2012). Combined effect of injection timing and combustion chamber geometry on the performance of a biodiesel fueled diesel engine. Energy, 47(1), 388-394. https://doi.org/10.1016/10.1016/j.energy.2012.09.059

Jindal, S., Nandwana, B. P., Rathore, N. S. and Vashistha, V. (2010). Experimental investigation of the effect of compression ratio and injection pressure in a direct injection diesel engine running on Jatropha methylester. Applied Thermal Engineering, 30(5), 442-448. https:// doi.org/10.1016/j.applthermaleng.2009.10.004

Kamil, D., Wierzbicki, S., Śmieja, M. and Mikulski, M. (2018). Comparison of Performance and Emissions of a CRDI Diesel Engine Fuelled with Biodiesel of Different Origin. Fuel, 212, 202-22. https://doi.org/10.1016/j.fuel.2017.09.112

Kannan, R. and Anand, R. (2012). Effect of injection pressure and injection timing on DI diesel engine fuelled with biodiesel from waste cooking oil. Biomass and Bioenergy, 46, 343-352. https://doi.org/10.1016/j.biombioe.2012.08.006

Khandal, S. V., Banapurmath, N. R., Gaitonde, V. N. and Hiremath, S. S. (2017). Paradigm Shift from Mechanical Direct Injection Diesel Engines to Advanced Injection Strategies of Diesel Homogeneous Charge Compression Ignition (HCCI) Engines- A Comprehensive Review. Renewable and Sustainable Energy Reviews, 70, 369-84. https://doi.org/10.1016/j.rser.2016.11.058

Kumar, V. M., Babu, A. V. and Kumar, P. E. (2018). Experimental Investigation on the Effects of Diesel and Mahua Biodiesel Blended Fuel in Direct Injection Diesel Engine Modified by Nozzle Orifice Diameters. Renewable Energy, 119, 388-99. https://doi.org/10.1016/j.renene.2017.12.007

Lee, C. S. (2016). Spray and Combustion Characteristics of Biodiesel/Diesel Blended Fuel in a Direct Injection Common-Rail Diesel. 130 (May 2008), 1-9. https:/ / doi.org/10.1115/1.2835354

Mohan, B., Yang, W., Raman, V., Lingam, V. S. and Chou, S. K. (2014). Optimization of biodiesel fueled engine to meet emission standards through varying nozzle opening pressure and static injection timing. Applied Energy, 130, 450-457. https://doi.org/10.1016/j.apenergy.2014.02.033

Nanthagopal, K., Ashok, B. and Raj, R. T. K. (2016). Influence of fuel injection pressures on Calophyllum inophyllum methyl ester fueled direct injection diesel engine. Energy Conversion and Management, 116, 165-173. https://doi.org/10.1016/j.enconman.2016.03.002 
Nwafor, O. M. I., Rice, G. and Ogbonna, A. I. (2000). Effect of advanced injection timing on the performance of rapeseed oil in diesel engines. Renewable Energy, 21(3-4), 433-444. https://doi.org/10.1016/S09601481(00)00037-9

Oner, C. and Altun, S. (2009). Biodiesel production from inedible animal tallow and experimental investigation of its use as Alternative fuel in a direct injection dieselengine. Applied Energy, 86(10), 2114-2120. https://doi.org/10.1016/j.apenergy.2009.01.005

Puhan, S., Jegan, R., Subbramanian, K. B. and Nagarajan, G. (2009). Effect of injection pressure on performance, emission and combustion characteristics of high linolenic linseed oil methyl ester in a DI diesel engine. Renewable Energy, 34(5), 1227-1233. https:/ / doi.org/10.1016/j.renene.2008.10.001

Sayin, C., Gumus, M. and Canakci, M. (2012). Effect of fuel injection pressure on the injection, combustion and performance characteristics of a DI diesel engine fueled with canola oil methyl esters-diesel fuel blends. Biomass and Bio energy, 46, 435-446. https://doi.org/10.1016/10.1016/j.biombioe.2012.07.016

Scholl, K. and Sorenson, S. (1993). Combustion of Soybean Oil Methyl Ester in a Direct Injection Diesel Engine. SAE Technical Paper 930934. https:/ / doi.org/10.4271/930934

Singh, A. P. (2018). Evaluation of Fuel Injection Strategies for Biodiesel-Fueled CRDI Engine Development and Particulate Studies. 140, 1-17. https://doi.org/10.1115/1.4039745 